\title{
Changes in the Consonant System of Pannonia Inferior, Dalmatia and Venetia et Histria
}

\author{
Attila Gonda \\ (Hungarian Academy of Sciences, Budapest)
}

\begin{abstract}
This study aims to classify the geographical variants of Vulgar Latin found in the inscriptions of Pannonia Inferior, Dalmatia and Venetia et Histria, and their provincial capitals Aquincum, Salona and Aquileia, based on the changes of their consonant system in order to investigate the possibilities whether a regional dialect area over the Alps-Danube-Adria region of the Roman Empire could have existed as suggested by József Herman. For the analysis, the provincial countryside and the provincial capitals are contrasted to each other as well as to the rest of the Latin speaking provinces of the Roman Empire. The relevant linguistic data are taken from the Computerized Historical Linguistic Database of Latin Inscriptions of the Imperial Age, and the statistical analysis applies the Herman method of calculating the relative distribution of diverse types of non-standard data found in the inscriptions. After the comparison of the phenomena of sonorization, degemination, assimilation and /b/ /w/ fusion between an earlier and later chronological period, a suggested map of dialectal variants of Vulgar Latin in the region will be hypothesized.
\end{abstract}

\section{Keywords}

Vulgar Latin; dialectology; regional diversification; consonant system; case system; inscriptions

\footnotetext{
The present paper has been prepared within the framework of the project OTKA (Hungarian Scientific Research Fund) No. K 108399 entitled "Computerized Historical Linguistic Database of Latin Inscriptions of the Imperial Age" (see http://lldb.elte.hu/) and of the project entitled "Lendület ('Momentum') Research Group for Computational Latin Dialectology" (Research Institute for Linguistics of the Hungarian Academy of Sciences).
} 


\section{Introduction}

After Jürgen Untermann's study, ${ }^{1}$ entitled Alpen-Donau-Adria, which described the Alps-Danube-Adria region as a united socio-political entity, József Herman proposed that this region, comprising the Augustan Regio X of Italia, also known as Venetia et Histria, the provinces of Dalmatia, Raetia, Noricum, Pannonia Inferior and Pannonia Superior, could be a good candidate as a larger geographic area for future research in Latin dialectology. ${ }^{2}$ This study is an experiment with Herman's suggestion by attempting to examine the consonant changes in some important centers of the proposed region with the purpose to explore the dialectal landscape of the area. The provinces included in the research are the most important centers of the Alps-Danube-Adria region, therefore their data should be able to give us a reliable sample of the variety of Latin spoken in the region. The linguistic data from the inscriptions used in this study are recorded in the Computerized Historical Linguistic Database of Latin Inscriptions of the Imperial Age (LLDB), which stores a nearly complete collection of non-standard linguistic phenomena from all published corpora of Latin inscriptions from our examined territories. Unfortunately, the number of these data from early Venetia-Histria, late Pannonia Inferior, including Aquincum, and late Dalmatia are insufficient for a solid statistical analysis, therefore any conclusion we draw must remain largely hypothetical, but we believe that, thanks to the systematic methodology, our results will still give a reliable insight into the regional diversification of the consonant system in the area.

\section{Methodology}

We will follow the methodology devised by Herman ${ }^{3}$ and look at the relative distribution of diverse types of non-standard data which are found in the inscriptions. We will analyze the changes in the consonant system by contrasting the data of an earlier period $\left(1^{\text {st }}-3^{\text {rd }} c . A D\right)$ with those of the later stage $\left(4^{\text {th }}-7^{\text {th }} c . A D\right)$. To enhance the possibility to find more details about the diversification of the area, we will compare the language of the inscriptions of the provincial capitals with those of the provincial country towns, and also with the rest of the provinces of the Roman Empire.

Before we could model the linguistic changes in the Vulgar Latin of our selected territories, the first stage of our work was the grouping of the various phenomena of the inscriptions into relevant categories that are helpful for our purposes. The result of this work, with the number of occurrences and the relative frequency of the linguistic and orthographic errors from the early period $\left(1^{\text {st }}-3^{\text {rd }}\right.$ centuries $)$ are represented in Table 1 , while Table 2 contains the data for the same categories from the later period $\left(4^{\text {th }}-7^{\text {th }}\right.$ cen-

1 Untermann (1980: pp. 45-63).

2 Herman (1983).

3 For the most detailed explanation of this methodology, see Herman (2000b) and Adamik (2012). 
turies). ${ }^{4}$ For comparison, the same categories of data from the rest of the Latin speaking provinces of the Roman Empire, except our three examined provinces, are shown in the first column of each table. ${ }^{5}$ Each category of linguistic and orthographic "error" or "mistake" (these words will be used simply to denote nonstandard phenomena without judgment) in the tables contains both the error indicated in the name of the category and its reverse variant: the reason for this kind of denotation is that the reverse of an error is usually caused by hypercorrection, which does not negate but rather confirms the existence of the sound change in question. ${ }^{6}$

We have lumped together in the tables - under the category Alii consonantismi - all error types which indicate sound changes that aren't universally considered distinguishing characteristics of any of the Romance languages (or which appeared in so insignificant numbers in all territories that the data would have been useless). The spelling errors listed as separate items in the tables are the ones relevant for our present study, and they shall be able to provide comprehensive insight to the dialectal classification of our territories. We have, however, fully excluded two types of categories, the Errores orthographici, data which are undoubtedly orthographical in nature (e.g. the confusion between the letters $\mathrm{C} \sim \mathrm{K} \sim \mathrm{Q}^{7}$ and $\mathrm{X} \sim \mathrm{CS}$ ), and the Errores technici, ${ }^{8}$ the purely technical errors of the lapicida (e.g. the carving of an E instead of F), in order to avoid the measuring of the quality of stonemasonry and to exclude some cultural factors that would come handy for a comprehensive analysis of the phonology of our provinces as a control group for refining the periodization of the completion of individual sound changes, but which would just over-complicate the simple profiling of errors that we need now for our purposes. For these reasons, Table 1 and Table 2 show only our selected error types in relation to the rest of the data.

We will include the group of the Errores quasi orthographici in the tables, which cover misspellings caused by sound changes that have more or less taken place in earlier periods, such as the disappearance of $/ \mathrm{h} /$ from pronunciation, but which are still not fully completed, so they can refine our picture about the relevance of actual phonetic developments. Some standard, universal Vulgar Latin sound changes, which still might

$4 \quad$ All statistics are counted from data according to the state of the LLDB in April, 2017.

5 There are a number of data that can be dated potentially both before and after 300 AD: these data were excluded from the analysis. Also excluded are data which could be explained by changes in the declension or conjugation systems, or by syntactical or stylistic reason. Data marked as fortasse recte in the LLDB database are likewise excluded. For the purpose of this research, I had to make some concessions for Aquincum and Pannonia Inferior, because data for the later period are extremely sparse there since the city was abandoned at the beginning of the 5th century. In the case of Aquincum, I included data that have been assigned to a wider possible dating and may have fallen either to the 3rd century or to the 4th.

6 Cravens (2002: pp. 56-57).

7 The confusions between $\mathrm{QV} \sim \mathrm{Q}, \mathrm{QV} \sim \mathrm{K}$ and $\mathrm{QV} \sim \mathrm{C}$ (when the letter $\mathrm{V}$ is missing or is erroneously added in the inscription) are not excluded from the statistics, because they indicate a real change in the pronunciation, the disappearance of the labial element of the labiovelar / kw/: these are added to the category of Alii consonantismi.

8 The carving of $\mathrm{C}$ instead of $\mathrm{G}$ (such as CONIVCI < coniugi) is counted among the excluded phenomena as a matter of writing technic which can usually be explained by a simplified or archaic writing style (ad analogiam C. = Gaius), since originally all $/ \mathrm{g} /$ sounds were denoted by the letter C. 
be in process in our discussed periods, but which have their origin in the republican period vernacular version of Classical Latin, are also included among the Errores quasi orthographici, such as the /ns/ > / s/ change and the disappearance of the " $m$ " caduca. These errors don't always reflect the sound changes of our examined period, but they are vestiges of the phonetic developments of earlier centuries, thus they are just a matter of orthography, and, as control group, they serve as a balancing factor in the statistics and help identify sound changes that are current, active developments in our examined period, and differentiate them from sound changes completed in earlier periods. These Errores quasi orthographici will show the degree of incorrect orthography, resulted from past sound changes and low quality of education of the stonemason and/or the customer. ${ }^{9}$

After this introduction to our methodology, we must identify those characteristic consonant changes which can serve as differentiating factors for the geographical classification of our six examined territories. They must be such consonant changes that are generally accepted as the differentiating characteristics in the classification of Romance languages, such as Eastern Romance and Western Romance, or Balkan Romance and Italo-Romance. Such characteristic changes in the consonant system are (1) the sonorization of voiceless plosives, (2) the degemination of double consonants, (3) the assimilation of consonant clusters, and (4) the merger of the $/ w / \sim / b /$, which is a type of lenition. These figures will be used for the examination of the consonant changes in the rest of this discussion.

\section{Examination of consonant changes}

\subsection{Sonorization in the early period}

One of the typical consonantal developments in Romance languages is the sonorization of voiceless plosives $(/ \mathrm{p} /, / \mathrm{t} /, / \mathrm{k} /)$. This phenomenon is one of the characteristics of the Romance dialects north and west of the La Spezia-Rimini or Massa-Senigallia line: the Gallo-Italian dialects and the languages of France and the Iberian peninsula have their intervocalic $/ \mathrm{p} /, / \mathrm{t} /, / \mathrm{k} /$ voiced, while the central and southern Italian dialects, Romanian and the extinct Dalmatian language preserved the original voiceless quality of consonants. ${ }^{10}$

Table 3 shows us the inscriptional errors concerning sonorization or desonorization in our six geographical units, ${ }^{11}$ listing their relative proportions as retrieved from Table 1. These two types of mistakes are to be studied together, as they are interconnected, and sometimes both can be sign of the same sound change. Misspelling of voiced consonants as voiceless can sometimes be a hypercorrective error, and if this is

9 Adamik (2012: pp. 123-139).

10 See Tamás (1983: pp. 66-68), Herman (2000a: pp. 45-47), Loporcaro (2011: p. 154).

11 With the exception of $/ \mathrm{g} />\mathrm{C}$ errors, see $\mathrm{n} .8$. 


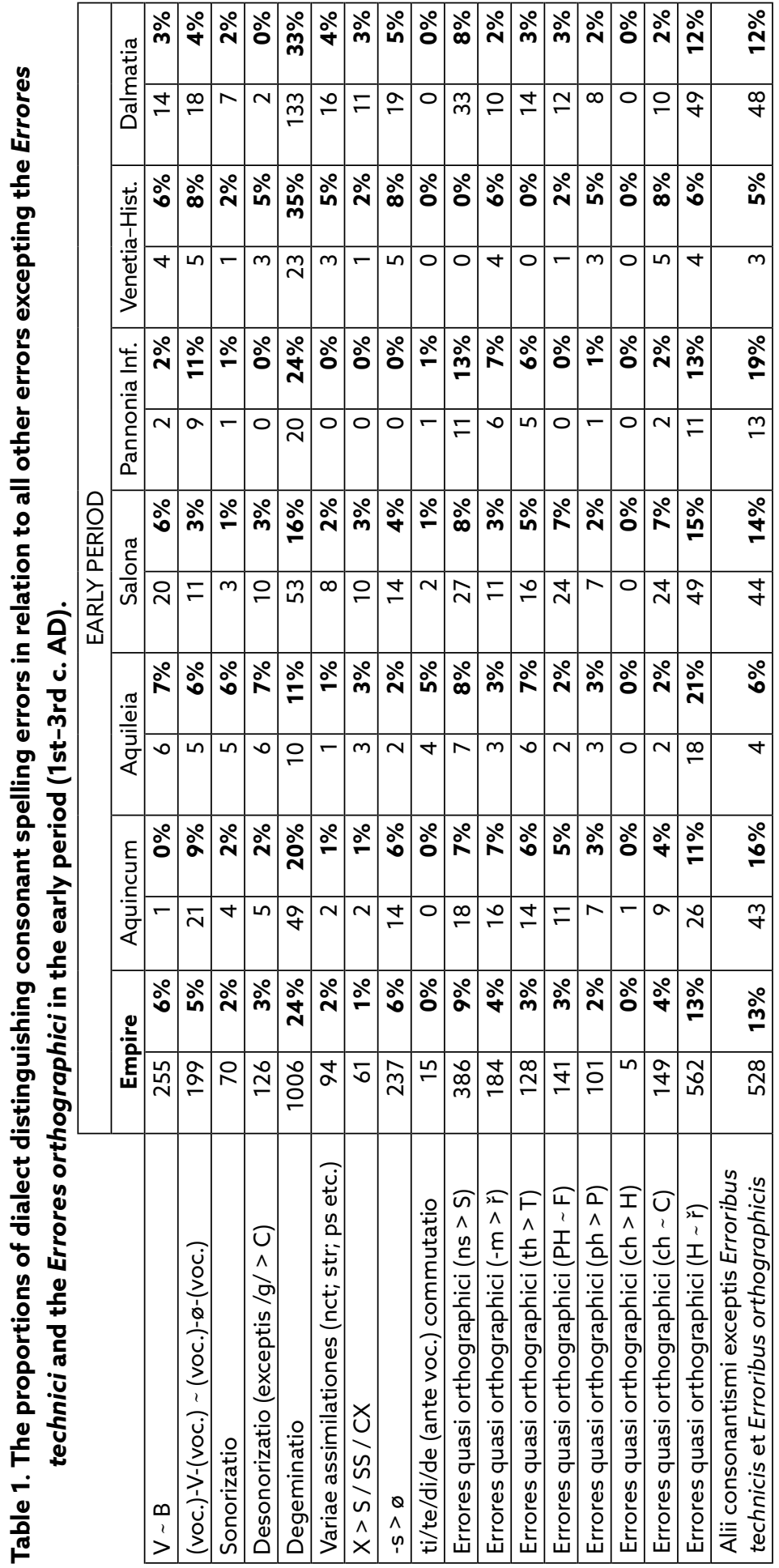




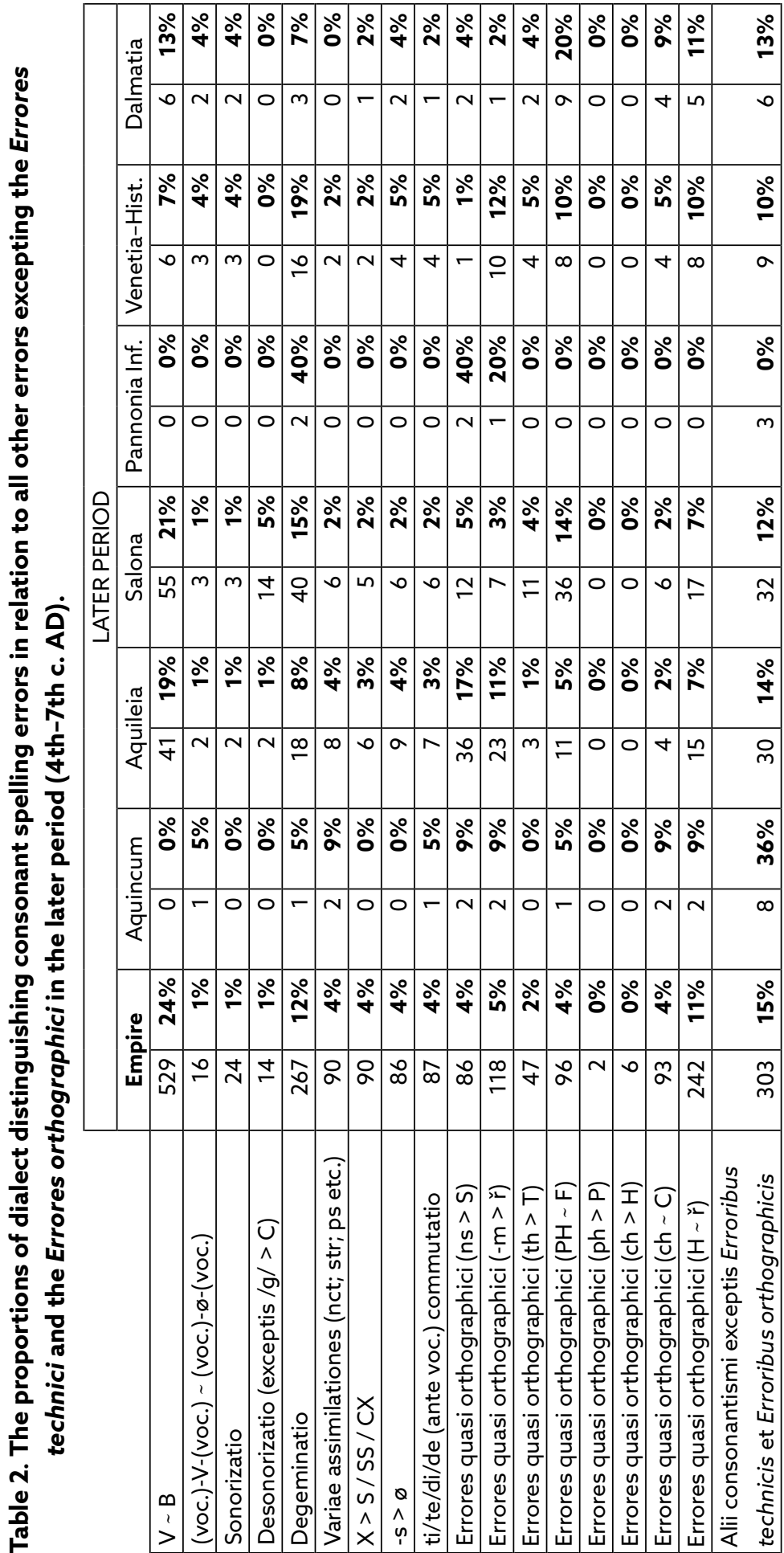


the case, it contributes to the relative ratio of sonorization. This means that we have to decide in each case whether the errors indicating desonorization are hypercorrections or the denotations of the actual of pronunciation. We know that there are no Romance languages that inherited the Latin voiced plosives in devoiced form from Vulgar Latin, even though we can find some counterexamples, such as the Catalan language, which devoiced the word final consonants after the elimination of the original Latin word ending vowels, however, this so called "final obstruent devoicing" in Catalan happened later during the Middle Ages as an independent development, and not as part of the Vulgar Latin developments. ${ }^{12}$ Therefore we are left to suppose that the phenomenon of desonorization must be, in the first place, a hypercorrective error in the Latin inscriptions, and, in the second place, it might be just a sign of some timorous first steps toward the devoicing of plosives, a process that never reached maturity and died out very soon. However, when the proportion of desonorization is as large as or even larger than - that of the sonorization in a given territory, it cannot be simply dismissed as hypercorrect spelling. Consequently, if the percentage of desonorization is significant, since without result in the Romance languages it can't be considered a full-strength permanent devoicing of the plosives, it may suggest instead a slightly different phonetic process, perhaps less of a devoicing or voicing, more of a general "sound weakening", a slurred or relaxed pronunciation, which appears in the confusion of the spelling of voiced and voiceless plosives. However, if the proportion of desonorization errors is much higher than the percentage of sonorization, it definitely must indicate at least a temporary tendency of devoicing.

Because of this ambivalent evaluation of the desonorization errors, when I categorized the examined territories according to their degree of sonorization, I took in consideration not only the amount of sonorization errors, but also the amount of desonorizations, and I counted their proportions related to each other, and weighted them into the decision.

Table 3. The proportions of spelling errors indicating sonorization and desonorization (1st-3rd c. AD).

\begin{tabular}{|l|r|r|r|r|r|r|r|}
\hline & & Aquileia & Aquincum & Dalmatia & Pan. Inf. & Salona & Ven-Hist. \\
\cline { 3 - 8 } EARLY PERIOD & Empire & \multicolumn{4}{|c|}{ Intensive sonorizatio } & & \multicolumn{2}{c|}{ Weaker sonorizatio } \\
\hline Sonorizatio & $\mathbf{2} \%$ & $6 \%$ & $2 \%$ & $2 \%$ & $1 \%$ & $1 \%$ & $2 \%$ \\
\hline Desonorizatio & $\mathbf{3} \%$ & $7 \%$ & $2 \%$ & $0 \%$ & $0 \%$ & $3 \%$ & $5 \%$ \\
\hline Combined & $\mathbf{5 \%}$ & $13 \%$ & $4 \%$ & $2 \%$ & $1 \%$ & $4 \%$ & $7 \%$ \\
\hline Ratio of sonor. ${ }^{13}$ & $\mathbf{6 7} \%$ & $46 \%$ & $50 \%$ & $100 \%$ & $100 \%$ & $25 \%$ & $29 \%$ \\
\hline
\end{tabular}

12 Lloret (2004: pp. 278-280).

13 The percentages given here as the ratio of sonorization are counted only from the relative percentages of sonorizatio and desonorizatio errors present in the table, not from their actual numbers of occurrence because these ratio percentages serve only as a rough approximation to indicate the degree of intensity of the phenomenon, and not as precise statistical data (consequently, they aren't used in further calculations). 
After the calculations in Table 3, we can divide our territories into a conservative and a sonorizating group: Aquileia, Aquincum and the Pannonian countryside, and Dalmatia belong to this sonorizating group, because they have either higher numbers of sonorization and desonorization errors combined - like Aquileia with $13 \%$ in sum and Aquincum where it's $4 \%$-, or their combined percentage, even if higher, has an overwhelming tendency toward sonorization rather than desonorization like the Pannonian, Dalmatian countryside, where all errors are exclusively sonorizations. To the conservative group belong Salona and provincial Venetia-Histria that have both a relatively lower or medium number of sonorization-desonorization percentage counted together, and, more importantly, have the lowest ratio of sonorization in relation to desonorization, Salona with $1 \%$ to $3 \%$, which is just only $25 \%$ sonorization to desonorization, and Venetia-Histria with $2 \%$ to $5 \%$, which is only $29 \%$ sonorization to desonorization, testifying about an inherently conservative character which is perhaps shaken by temporary pronunciation habits, but is not about to change.

\subsection{Degemination in the early period}

Now let's see another, related, phenomenon: the degemination of double consonants. The simplification of geminates, that is, double consonants, is another phenomenon whose occurrence is split by the Massa-Senigallia line: most of the Romance languages underwent a simplification of geminates, a defining characteristic of Western Romance, but Italian dialects south of the Massa-Senigallia line kept their double consonants. ${ }^{14}$ In our statistics (Table 4) the reverse of this phenomenon, i.e. when a double consonant is standing for simple one, is grouped also under the category of degemination (as hypercorrection, see our chapter 2. Methodology), because degemination is always and in every territory at least two times more frequent than consonant gemination. By observing the percentages of degemination errors, provincial Dalmatia and Venetia-Histria can be grouped together as the ones most actively exhibiting symptoms of degemination, while Aquileia and the Pannonia Inferior countryside follow with about a ten percent lower, then Salona and Aquincum with almost a twenty percent lower degree, so they are grouped together as less intensely degeminating areas.

Table 4. The proportions of spelling errors indicating degemination (1st-3rd c. AD).

\begin{tabular}{|c|r|r|r|r|r|r|r|}
\hline & & Aquileia & Salona & Aquincum & Pan. Inf. & Dalmatia & Ven-Hist. \\
\cline { 3 - 8 } EARLY PERIOD & Empire & \multicolumn{5}{|c|}{ Weaker degeminatio } & \multicolumn{2}{|c|}{ Intensive degeminatio } \\
\hline Degemination & $\mathbf{2 4 \%}$ & $11 \%$ & $16 \%$ & $20 \%$ & $24 \%$ & $33 \%$ & $35 \%$ \\
\hline
\end{tabular}

14 See Väänänen (1981: pp. 58-60), Tamás (1983: pp. 83-85), Loporcaro (2011: pp. 150-153). 


\subsection{Assimilation in the early period}

Table 5. The proportions of spelling errors indicating assimilation (1st-3rd c. AD).

\begin{tabular}{|c|c|c|c|c|c|c|c|}
\hline \multirow[b]{2}{*}{ EARLY PERIOD } & \multirow[b]{2}{*}{ Empire } & Pan. Inf. & Aquincum & Aquileia & Salona & Dalmatia & Ven-Hist. \\
\hline & & \multicolumn{4}{|c|}{ Weaker assimilatio } & \multicolumn{2}{|c|}{ Intensive assimilatio } \\
\hline Assimilationes & $2 \%$ & $0 \%$ & $1 \%$ & $1 \%$ & $2 \%$ & $4 \%$ & $5 \%$ \\
\hline$X>S / S S / C X$ & $1 \%$ & $0 \%$ & $1 \%$ & $3 \%$ & $3 \%$ & $3 \%$ & $2 \%$ \\
\hline
\end{tabular}

The next related consonant change phenomenon is the simplification of consonant clusters, which was somewhat less intense in the East. ${ }^{15}$ Examples include the assimilation of the labial and velar plosives to dental plosives, such as settem for septem and otto for octo, but I also included in this category all assimilation changes that point towards Romance developments, like the assimilation of /nd/,/nm/ or /gn/ to double /nn/,/rs/ or $/ \mathrm{ps} /$ to double $/ \mathrm{ss} /$, however, usually more than half of the assimilation concerns the plosive clusters. The consonant cluster $/ \mathrm{ks} /$, denoted by the letter $\mathrm{X}$, is represented in Table 5 separately due to its large number so as not to obscure the proportion of other diverse forms of assimilations, but it is taken into consideration for the classification of the provinces. The comparison of the numbers gives us provincial Venetia-Histria and Dalmatia as the most advanced territories in respect to the intensity of their assimilation tendencies, while the rest of the cities and the countryside of Pannonia will belong to the weak group.

At this point, we are happily surprised to notice that Aquincum and Aquileia belonged to the same group in all three consonant change categories, and provincial Dalmatia sided together with provincial Venetia-Histria in two of the three comparisons: the same is true about Aquileia, Aquincum, Pannonia Inferior and Salona. Simplification of geminates, assimilation of consonant clusters and desonorization of voiced consonants are all related phenomena of consonant lenition: similar tendencies in local vernaculars are probably not just random resemblance. It seems we are finally going to capture a shared pattern in the consonant system of our Alps-Adria-Danube provinces. In order to confirm our suspicions, let's see how our provinces behave in the later period.

\subsection{Sonorization in the later period}

A caveat is necessary before the following analysis and conclusions drawn for the later period because in some cases extremely low numbers underlie the (sometimes quite high) percentages especially in the case of late Pannonia Inferior and Aquincum. For the actual numbers of data see Table 2.

15 Tamás (1983: pp. 74-83), Herman (2000a: pp. 47-48), Loporcaro (2011: pp. 91-94). 
Table 6. The proportions of spelling errors indicating sonorization and desonorization (4th-7th c. AD).

\begin{tabular}{|c|c|c|c|c|c|c|c|}
\hline \multirow[b]{2}{*}{ LATER PERIOD } & \multirow[b]{2}{*}{ Empire } & Aquincum & Pan. Inf. & Salona & Aquileia & Dalmatia & Ven-Hist. \\
\hline & & \multicolumn{4}{|c|}{ Weaker sonorizatio } & \multicolumn{2}{|c|}{ Intensive sonorizatio } \\
\hline Sonorizatio & $1 \%$ & $0 \%$ & $0 \%$ & $1 \%$ & $1 \%$ & $4 \%$ & $4 \%$ \\
\hline Desonorizatio & $1 \%$ & $0 \%$ & $0 \%$ & $5 \%$ & $1 \%$ & $0 \%$ & $0 \%$ \\
\hline Combined & $2 \%$ & $0 \%$ & $0 \%$ & $6 \%$ & $2 \%$ & $4 \%$ & $4 \%$ \\
\hline Ratio of sonor. ${ }^{16}$ & $50 \%$ & $0 \%$ & $0 \%$ & $17 \%$ & $50 \%$ & $100 \%$ & $100 \%$ \\
\hline
\end{tabular}

Sonorization is, again, a weak phenomenon in Salona as seen in Table 6, even weaker than it was in the $1^{\text {st }}-3^{\text {rd }}$ centuries, decreasing from $25 \%$ to $17 \%$ (which we obtain by counting the ratio of its $1 \%$ sonorization to its $5 \%$ desonorization), and the Dalmatian countryside is still the leading center of voicing the Latin consonants within the region. However, the provincial capitals Aquileia and Aquincum, and their provincial territories Pannonia Inferior and the Venetia-Histria countryside changed sides. And it was not just simply a change in proportions between sonorization and desonorization errors: they changed so much that they don't even produce any examples for desonorization. This further corroborates our hypothesis that previously the relatively higher percentage of desonorization errors in these areas was not a sign of desonorization process but rather a spelling confusion induced by a general weakening of voiced plosives that did not result in a substantial phonetic change.

At this point, we must notice an interesting correlation between sonorization, degemination and assimilation intensities in the earlier and later historical periods. In those places where a stronger sonorization was coupled with a less forceful degemination and assimilation in the earlier period, we find less intensive sonorization in the later period (see Aquincum, Aquileia, Pannonia Inferior and Venetia-Histria); and respectively, where an initially weaker sonorization met a more intense degemination and assimilation process, the degree of sonorization, on the contrary, became amplified (see Venetia-Histria). The countryside of Dalmatia had strong degrees on both accounts, and it remains in this category. From this we can conjecture that the initial intensity of degeminating and desonorizing tendencies might have influenced the later developments of the sonorization process, or at least they were in correlation to each other, which seems a logical position to me, given their similar nature as consonant lenitions. Let's see if this holds true for the other two phenomena, and let's examine the status of degemination and assimilation for the $4^{\text {th }}-7^{\text {th }}$ centuries.

\subsection{Degemination in the later period}

By looking at the figures of Table 7, we can see that the process of degemination remains invariably less productive in Aquileia and Aquincum, but in this later period the Dal-

16 See n. 13. 
matian countryside seems to fall in this category as well, though the overall scarcity of data (of all error types) from Dalmatia compels us to be suspicious about any surprising turns. If the low proportion of degemination in Dalmatia is not caused by statistical distortion, then perhaps it's because the process of degemination has run its course in Dalmatia, and, after having done its work with success, other phonetic changes are becoming more active and statistically more significant. Degemination in early rural Dalmatia might have had influenced its capital, Salona, too, which has changed sides and is now part of the intensively degeminating group. That the result of degemination must have been permanent in the area is also attested by the extinct Dalmatian Romance language which had only simple consonants. It is interesting to note that this switch in position concerning degemination that happened in this later period with Salona and Dalmatia is in negative correlation with their intensity of all three examined phonetic processes in the early period, and with the constant amplitude of their degree of sonorization between the early and the later period: Salona was initially weak in all three categories and showed a lower percentage in sonorization in both periods, and this combination resulted in an increase of the relevance ${ }^{17}$ of degemination for the later period; Dalmatia was producing high figures in the early centuries in all three categories, which was combined with higher intensity in sonorization in both periods, and it is now losing the momentum in degemination. The present study is not the place to explore the reasons behind this, which may be caused even just by a statistical distortion due to the lower number of inscriptions, however it's worth it to mention that Dalmatia was affected by significant migration processes as the Romans evacuated the provinces of Pannonia, Moesia and Dacia. The new inhabitants coming from North and East, with the simultaneous decrease of the number of native Dalmatian Romans moving to Italy, might have left an impact on the linguistic tendencies. ${ }^{18}$

Table 7. The proportions of spelling errors indicating degemination (4th-7th c. AD).

\begin{tabular}{|l|r|r|r|r|r|r|r|}
\hline & & Aquincum & Dalmatia & Aquileia & Salona & Ven-Hist. & Pan. Inf. \\
\cline { 3 - 7 } LATER PERIOD & Empire & \multicolumn{2}{|c|}{ Weaker degeminatio } & \multicolumn{3}{|c|}{ Intensive degeminatio } \\
\hline Degemination $^{19}$ & $\mathbf{1 2} \%$ & $5 \%$ & $7 \%$ & $8 \%$ & $15 \%$ & $19 \%$ & $40 \%$ \\
\hline
\end{tabular}

Although the low number of data doesn't allow us to be confident about that either (the $40 \%$ most certainly is a statistical distortion due to the low number of inscriptions), the countryside of Pannonia Inferior also seems to be joining its surroundings VenetiaHistria and Salona with intensive degemination. In general, it looks like that the entire region is moving toward degemination in this later period.

17 It's a relative increase in how relevant the phenomenon is in comparison to the degree that this phenomenon occupies in the other examined provinces.

18 Mócsy (1974: p. 374) discusses the migration from the Eastern provinces; about another similar phenomenon in the region, see Gonda (2015).

19 The very high $40 \%$ rate for Pannonia is based on 2 pieces of data only, see Table 2. 


\subsection{Assimilation in the later period}

Table 8. The proportions of spelling errors indicating assimilation in relation to all other errors excepting the Errores technici and Errores orthographici in the later period (4th-7th c. AD).

\begin{tabular}{|c|c|c|c|c|c|c|c|}
\hline \multirow[b]{2}{*}{ LATER PERIOD } & \multirow[b]{2}{*}{ Empire } & Aquincum & Aquileia & Salona & Ven-Hist. & Dalmatia & Pan. Inf. \\
\hline & & \multicolumn{2}{|c|}{ Intensive assimilatio } & \multicolumn{4}{|c|}{ Weaker assimilatio } \\
\hline Assimilationes $^{20}$ & $4 \%$ & $9 \%$ & $4 \%$ & $2 \%$ & $2 \%$ & $0 \%$ & $0 \%$ \\
\hline $\mathrm{X}>\mathrm{S} / \mathrm{SS} / \mathrm{CX}$ & $4 \%$ & $0 \%$ & $3 \%$ & $2 \%$ & $2 \%$ & $2 \%$ & $0 \%$ \\
\hline
\end{tabular}

The figures for assimilation errors for the later period, including the spelling errors of the letter X, put all of our examined territories in the same group of weak assimilation, except Aquileia, and, in a lesser degree, Aquincum (where, despite the high percentage, the number of data is very low). We have already seen that in this later period our cities and provinces were moving slowly away from their initial grouping to the one usually dominated by provincial Venetia-Histria (and the other provincial peripheries) and frequently characterized by Eastern Romance properties. The assimilation errors confirm this observation that we made at the discussion of degemination errors. As for Aquincum, since its assimilation percentage is two times higher than the combined percentage of any of the other territories with the exception of Aquileia, I think it's acceptable to group it together with Aquileia, even though the low number of data cannot confirm this satisfactorily.

\subsection{Correlation of $V \sim B$ confusions and intervocalic $V$ drops in the two periods}

We have completed a historical overview of three important consonant changes, however, we have not yet finished the analysis. Another important and distinguishing feature of Vulgar Latin dialects is the merge of the $\mathrm{V} \sim \mathrm{B}$ consonants,,$^{21}$ and as it is a very peculiar phenomenon, we are dedicating a separate chapter to its discussion. If we compare the relative frequency of the $\mathrm{V} \sim \mathrm{B}$ confusions and the drop of the intervocalic $\mathrm{V}$ both in the early period and in the later period (Table 9 ), we can see that the rate of the $\mathrm{B} \sim \mathrm{V}$ confusion becomes higher, and the rate of the elimination of the intervocalic $\mathrm{V}$ becomes lower. Béla Adamik in his recent study ${ }^{22}$ has demonstrated a correlation between the increase of the $\mathrm{V} \sim \mathrm{B}$ confusion and the decrease of the loss of the intervocalic / w/ (written as $\mathrm{V}$ ) that is discernible with the progress of time throughout the provinces of the empire. Adamik explains that the merger of $/ \mathrm{w} /$ (spelled V) and /b/ (spelled B) to the bilabial fricative $/ \beta /$ in word-medial, intervocalic positions, and the loss of the intervo-

20 The comparatively high 9\% rate for later Aquincum is based on 2 pieces of data only, see Table 2.

21 Väänänen (1981: pp. 50-51 on intervocalic/w/ drop; pp. 56-58 on B V fusion). Also compare Tamás (1983: pp. 61-62) and Herman (2000a: pp. 45-47).

22 Adamik (2017: pp. 25-36). 
calic /w/ (spelled V) are in complementary distribution with each other: the higher the relative frequency of drop of the intervocalic / w/ in a region, the lower the percentage of the $\mathrm{V} \sim \mathrm{B}$ confusion is there.

Table 9. The proportions of spelling errors indicating $V^{\sim} B$ merger and the loss of intervocalic $V$ (4th-7th c. AD).

\begin{tabular}{|c|c|c|c|c|c|c|c|}
\hline \multirow[b]{2}{*}{ EARLY PERIOD } & \multirow[b]{2}{*}{ Empire } & Salona & Aquileia & Ven-Hist. & Dalmatia & Pan. Inf. & Aquincum \\
\hline & & \multicolumn{2}{|c|}{ Intensive $V \sim B$ merger } & \multicolumn{4}{|c|}{ Weaker $V \sim B$ merger } \\
\hline V $\mathrm{B}$ merger & $6 \%$ & $6 \%$ & $7 \%$ & $6 \%$ & $3 \%$ & $2 \%$ & $0 \%$ \\
\hline Intervoc. V ø & $5 \%$ & $3 \%$ & $6 \%$ & $8 \%$ & $4 \%$ & $11 \%$ & $9 \%$ \\
\hline \multirow[b]{2}{*}{ LATER PERIOD } & \multirow[b]{2}{*}{ Empire } & Salona & Aquileia & Dalmatia & Ven-Hist. & Pan. Inf. & Aquincum \\
\hline & & \multicolumn{2}{|c|}{ Intensive $V \sim B$ merger } & \multicolumn{4}{|c|}{ Weaker $V \sim B$ merger } \\
\hline V $\sim B$ merger & $24 \%$ & $21 \%$ & $19 \%$ & $13 \%$ & $7 \%$ & $0 \%$ & $0 \%$ \\
\hline Intervoc. V ø & $1 \%$ & $1 \%$ & $1 \%$ & $4 \%$ & $4 \%$ & $0 \%$ & $5 \%$ \\
\hline
\end{tabular}

How does this complementary distribution appear in our six geographical units? Salona has $6 \%$ of $\mathrm{V} \sim \mathrm{B}$ confusions, larger by $3 \%$ than the intervocalic elimination of $\mathrm{V}(3 \%)$. Aquileia has $7 \%$ and $6 \%$, its $\mathrm{V} \sim \mathrm{B}$ confusion ratio is larger by $1 \%$ than its $\mathrm{V}$-drop. The difference in the provincial areas of Dalmatia and Venetia-Histria are in the negative, they show a larger proportion of intervocalic $\mathrm{V}$-drops than $\mathrm{V} \sim \mathrm{B}$ confusion. Pannonia Inferior and Aquincum are disastrous, they have a $\mathrm{V}$-drop larger by $9 \%$ than $\mathrm{V} \sim \mathrm{B}$ confusions. Based on Adamik's observations, we should expect an increase of $\mathrm{V} \sim \mathrm{B}$ confusions in Salona and Aquileia, where the $\mathrm{V} \sim \mathrm{B}$ confusions are already prevalent, and a further decrease in Aquincum and rural Pannonia Inferior, where they are already the lowest. What we see in the later period it completely proves the thesis of Adamik: we find $0 \%$ of $\mathrm{V} \sim \mathrm{B}$ confusions in Aquincum and Pannonia, but $19 \%$ and $21 \%$ in Aquileia and Salona. Based upon our findings in our six territories, we could go even a step further and suggest that the correlation between $\mathrm{V} \sim \mathrm{B}$ confusion and intervocalic $\mathrm{V}$-drop does not just simply consist of their opposing distribution and increase in time for the $\mathrm{V} \sim \mathrm{B}$ merger if large proportion is granted in the early period, but the increase of the $\mathrm{V} \sim \mathrm{B}$ confusions is actually dependent on, and predictable from, the size of the positive difference between the proportion of the $\mathrm{V} \sim \mathrm{B}$ confusions and the $\mathrm{V}$-drop. The larger this difference is in favor of the $\mathrm{V} \sim \mathrm{B}$ confusion, the higher the percentage of the $\mathrm{V} \sim \mathrm{B}$ confusion will be in the later period; and if the $\mathrm{V}$-drop is more frequent in the early period than in the $\mathrm{V} \sim \mathrm{B}$ merger, than it signals that the $\mathrm{V} \sim \mathrm{B}$ merger will probably disappear altogether.

How do our six territories, based on the degree of their $V \sim B$ merger, fit into the dialectal grouping that has been already taking shape? Salona and Aquileia have a strongly intensive B V merger, Dalmatia and Venetia-Histria a moderate one, and Pannonia Inferior and its capital lose this phenomenon by the later period completely. We saw that Aquileia, Salona, the countryside of Dalmatia are sometimes similar, so their repeated similarity again fits well into the picture, even if Dalmatia has very few $\mathrm{V} \sim \mathrm{B}$ confusions: it still has a considerable proportion. We can put Venetia-Histria, as usual, to the second group due to its low numbers, even though one could argue that it belongs to the same 
group as Dalmatia as their figures are close. However, since Venetia-Histria has just half the percentage of Dalmatia, it's justified to separate them. The allocation of Aquincum in the same group with Venetia-Histria is the only anomalous point, because it has been so far always in a different group than Venetia-Histria; otherwise the result of this grouping is in harmony with the previous groupings.

\section{Conclusion}

After having gone through the analyses of these characteristic factors that usually define the dialectal classification of Romance languages, we have obtained a schematic "map of dialects" showing Aquileia, Aquincum consistently belonging together, the peripheries of Pannonia Inferior and Salona sometimes siding with Aquincum and Aquileia, sometimes with the provincial peripheries of Venetia-Histria and the countryside of Dalmatia, which are, in turn, consistently at the other end of the spectrum. This mapping of the dialects (or local variations) is presented in Table 10, but we should note that due to the statistically low amounts of data (especially from the later period), this classification had to be quite hypothetical. With this caveat in our mind, we can summarize the results by concluding that, in the $1^{\text {st }}-3^{\text {rd }}$ centuries, Aquileia, Aquincum together with its province Pannonia Inferior, and Salona might have constituted one dialectal block in the region, while the peripheral areas of Venetia-Histria and Dalmatia probably started to develop a different - "peripheral" - dialect. In some phenomena, like Aquincum and Pannonia Inferior in the lack of $\mathrm{B} \sim \mathrm{V}$ confusion and the preeminence of the dropping of the intervocalic / $\mathrm{w} /$, or Salona in the lack of sonorization, drew near to this "peripheral" block, but otherwise remained closer to the block of Aquileia, which we could label as "urban" in contrast to "peripheral". From the $4^{\text {th }}$ century onwards, Pannonia Inferior (if we can accept what the painfully few data attested from the period suggest) joins the "peripheral" block in almost all aspects, and Salona becomes better assimilated into its Dalmatian provincial surroundings by starting to simplify its double consonants, but it also retains properties that link it to the "urban" block, so we cannot yet fully assign it to the "peripheral" block, just to somewhere in between.

The "urban" block in the early period is characterized by the sonorization of the intervocalic voiceless plosives, by a conservative attitude toward geminates and consonant clusters, and by the merger of the /b/ and /w/ sounds; but in the later period the sonorization process stops and gives place to an increased degree of assimilation of consonant clusters: this result resembles the Italian Romance dialects south of the Massa-Senigallia line and the Western Romance dialects in a smaller extent. The "peripheral" group can be described in the early period by the lack of sonorization and of $/ \mathrm{b} / \sim / \mathrm{w} /$ merger, and by intensive degemination and assimilation, where the assimilation will be replaced by the process of sonorization in the later period: this outcome is partially reminiscent of the Eastern Romance languages. Over time, there seems to be a tendency for all the examined territories, with the exception of Aquileia, to move toward the "peripheral" dialect group, that is, a mixed form of Eastern Romance. 
Table 10. The classification of the examined territories in dialectal groups.

\begin{tabular}{|c|c|c|c|c|c|c|c|c|}
\hline \multicolumn{9}{|c|}{ EARLY PERIOD $\left(1^{\text {st }}-3^{\text {rd }}\right.$ centuries $)$} \\
\hline $\begin{array}{c}\text { intensive } \\
\text { sonorizatio }\end{array}$ & Aquileia & Aquincum & Pan. Inf. & Dalmatia & & Salona & Ven-Hist. & $\begin{array}{c}\text { weak } \\
\text { sonorizatio }\end{array}$ \\
\hline $\begin{array}{c}\text { weak } \\
\text { degeminatio }\end{array}$ & Aquileia & Aquincum & Pan. Inf. & Salona & & Dalmatia & Ven-Hist. & \begin{tabular}{|c|} 
intensive \\
degeminatio
\end{tabular} \\
\hline $\begin{array}{c}\text { weak } \\
\text { assimilatio }\end{array}$ & Aquileia & Aquincum & Pan. Inf. & Salona & & Dalmatia & Ven-Hist. & $\begin{array}{l}\text { intensive } \\
\text { assimilatio }\end{array}$ \\
\hline $\begin{array}{c}\text { intensive } \\
\mathbf{V} \sim \mathrm{B} \text { merger }\end{array}$ & Aquileia & & & Salona & Aquincum Pan. Inf. & Dalmatia & Ven-Hist. & $\begin{array}{c}\text { weak } \\
\text { V B merger }\end{array}$ \\
\hline \multicolumn{9}{|c|}{ LATER PERIOD $\left(4^{\text {th }}-7^{\text {th }}\right.$ centuries $)$} \\
\hline \begin{tabular}{c|} 
weak \\
sonorizatio
\end{tabular} & Aquileia & Aquincum & Pan. Inf. & Salona & & Dalmatia & Ven-Hist. & $\begin{array}{c}\text { intensive } \\
\text { sonorizatio }\end{array}$ \\
\hline $\begin{array}{c}\text { weak } \\
\text { degeminatio }\end{array}$ & Aquileia & Aquincum & & Dalmatia & Pan. Inf. & Salona & Ven-Hist. & $\begin{array}{c}\text { intensive } \\
\text { degeminatio }\end{array}$ \\
\hline $\begin{array}{c}\text { intensive } \\
\text { assimilatio }\end{array}$ & Aquileia & Aquincum & & & Salona Pan. Inf. & Dalmatia & Ven-Hist. & $\begin{array}{c}\text { weak } \\
\text { assimilatio }\end{array}$ \\
\hline $\begin{array}{c}\text { intensive } \\
V \sim B \text { merger }\end{array}$ & Aquileia & & & Salona & Aquincum Pan. Inf. & Dalmatia & Ven-Hist. & $\begin{array}{c}\text { weak } \\
\text { V } \text { B merger }\end{array}$ \\
\hline
\end{tabular}

Although we didn't examine all types of consonant changes, but the classification that resulted from the reviewed consonants can be supported also by the statistics of the dropping of the "- $m$ " caduca: in Table 1 and 2 we can see that this phenomenon in the early period is most frequent in Venetia-Histria, Pannonia Inferior and Aquincum (6-7\%), the rest - the more conservative ones - can be put in the "urban" group with Aquileia. Later, however, Aquileia grows almost equal in proportion, though Venetia-Histria and Pannonia still lead. The inclusion of the elimination or retention of the word final /-s/ in the study - another phenomenon that distinguishes dialects - would not change the picture, either: first Venetia-Histria $(8 \%)$ is accompanied by Dalmatia and Aquincum $(5-6 \%)$ as the more intensive eliminators, while Aquileia has just $2 \%$ and can be put in the more conservative "urban" group with the rest. In the $4^{\text {th }}-7^{\text {th }}$ centuries, Venetia-Histria and Dalmatia still stand out (5-4\%), but Aquileia has now similar numbers. ${ }^{23}$ If we look at the various commutations of the /-ti/te/di/de-/ syllables standing before vowel, Aquileia seems, again, to be set apart from Venetia-Histria and the rest of our examined territories both in the early and the later periods, but whereas in the early stage it is distinguished by the highest percentage (5\%), while the rest of the territories don't show signs of /-ti/te/di/de-/ commutation, in the late centuries it is much less preeminent in this phenomenon, and its numbers are almost as low as those of the more conservative group of Pannonia, Dalmatia and Salona; Venetia-Histria leads in the innovativeness, again.

Perhaps the most exciting question that arises from the conclusions is what reason co-

23 Although Venetia-Histria is north of the Massa-Senigallia line, and it should retain the /-s/, almost all Northern Italian dialects lost the word final /-s/ during later developments, so the weakening of the position of the /-s/ should not be counted as entirely against the nature of Gallo-Italian Romance languages north of the Massa-Senigallia line. 
uld explain that Venetia-Histria and Aquileia stand consistently at the opposite ends of the classification when we would expect them to be more similar. A possible explanation could be that Aquileia, as a large metropolis, was one of the most important commercial and administrative centers, a melting pot of peoples coming from all over the empire: the Latin spoken here did not clearly represent one local dialect, but it was blended by other Vulgar Latin phenomena from many provinces of the empire. If we compare the percentages of Aquileia with the statistics of the rest of the empire in Table 1 and 2, we can notice that Aquileia produces very similar figures to the imperial average. On the other hand, it's not inconceivable to suppose that it was both the population as colonists and the Northern Italic Latin of rural Venetia-Histria that spread over the provinces of the Alps-Danube-Adrian region, influencing the language of Dalmatia, and with time, Pannonia Inferior. The same can be said about Salona and Aquincum which as provincial centers were also exposed to great "international" influence: Salona, as a larger city, in a greater extent, Aquincum in a lesser extent. With time, however, and with the isolation of the area during the final years of the empire, Salona was cut off from the interprovincial influence and became influenced only by its own provincial surroundings, thus explaining how its Latin become more similar to rural Dalmatia for the later period. Aquileia, even if in a smaller extent, shows a similar trend of adaptation to Venetia-Histria in the later period after the strict ties to the "global" Roman metropolitan centers were increasingly loosened. These hypotheses are by no means conclusive though, and many questions remain open, but it seems we are now somewhat closer to the final answers, as we have identified at least two variants of the Latin spoken across Pannonia Inferior, Dalmatia and Venetia-Histria and the tendency of these provinces toward the Eastern Romance consonant system.

\section{Bibliography}

Adamik, B. (2012). In Search of the Regional Diversification of Latin: Some Methodological Considerations in Employing the Inscriptional Evidence. In F. Biville et al. (Eds.), Latin vulgaire - latin tardif IX. Actes du IXe colloque international sur le latin vulgaire et tardif, Lyon, 6-9 septembre 2009 (pp. 123-139). Lyon: Maison de l'Orient et de la Méditerrané.

Adamik, B. (2017). On the Vulgar Latin merger of /b/ and /w/ and its correlation with the loss of intervocalic /w/: Dialectological evidence from inscriptions. Pallas, 103, 25-36.

Cravens, T. D. (2002). Comparative historical dialectology: Italo-Romance clues to Ibero-Romance sound change. Philadelphia: John Benjamins Publishing.

Gonda, A. (2015). Aquincum latin nyelve. In I. Bárány, G. Bolonyai, A. Ferenczi, \& Á. Vér (Eds.), Studia Classica (pp. 317-338). Budapest: ELTE.

Herman, J. (1983). Le latin dans les provinces danubiennes de l'Empire romain. Problemes et perspectives de la recherche. In W. Haase (Ed.), Aufstieg und Niedergang der römischen Welt (Vol. II, 29, 2; pp. 1089-1106). Berlin: de Gruyter.

Herman, J. (2000a). Vulgar Latin. University Park, PA: The Pennsylvania State University Press. Herman, J. (2000b). Differenze territoriali nel latino parlato dell'Italia tardo-imperiale: un contri- 
buto preliminare. In J. Herman, \& A. Marinetti (Eds.), La preistoria dell Italiano. Atti della Tavola Rotonda di Linguistica Storica. Università Ca’ Foscari di Venezia 11-13 giugno 1998 (pp. 124-135). Tübingen: Niemeyer.

Lloret, M.-R. (2004). The Phonological Role of Paradigms: The case of insular Catalan. In J. Auger, J. C. Clements, \& B. Vance (Eds.), Contemporary Approaches to Romance Linguistics: Selected Papers from the 33rd Linguistic Symposium on Romance Languages (Current Issues in Linguistic Theory, 258; pp. 275-298). Philadelphia: John Benjamins.

Loporcaro, M. (2011). Phonological Processes. In M. Maiden et al. (Eds.), The Cambridge History of the Romance Languages (Vol. I.; pp. 109-154). Cambridge: Cambridge University Press.

Mócsy, A. (1974). Pannonia and Upper Moesia: A History of the Middle Danube Provinces of the Roman Empire. London - Boston: Routledge \& Paul.

Tamás, L. (1983). Einführung in die historisch-vergleichende romanische Sprachwissenschaft. Würzburg: Wissenschaftlicher Verlag A. Lehmann Gerbrunn.

Untermann, J. (1980). Alpen-Donau-Adria. In G. Neumann, \& J. Untermann (Eds.), Die Sprachen im römischen Reich der Kaiserzeit (Beihefte der Bonner Jahrbücher, Bd. 40). Köln - Bonn: Habelt.

Väänänen, V. (1981³). Introduction au latin vulgaire. Paris: Klincksieck.

Attila Gonda / gonda.attila@nytud.mta.hu

Research fellow at Lendület ('Momentum') Research Group for Computational Latin Dialectology Research Institute for Linguistics of the Hungarian Academy of Sciences

Benczúr u. 33, 1068 Budapest, Hungary 
